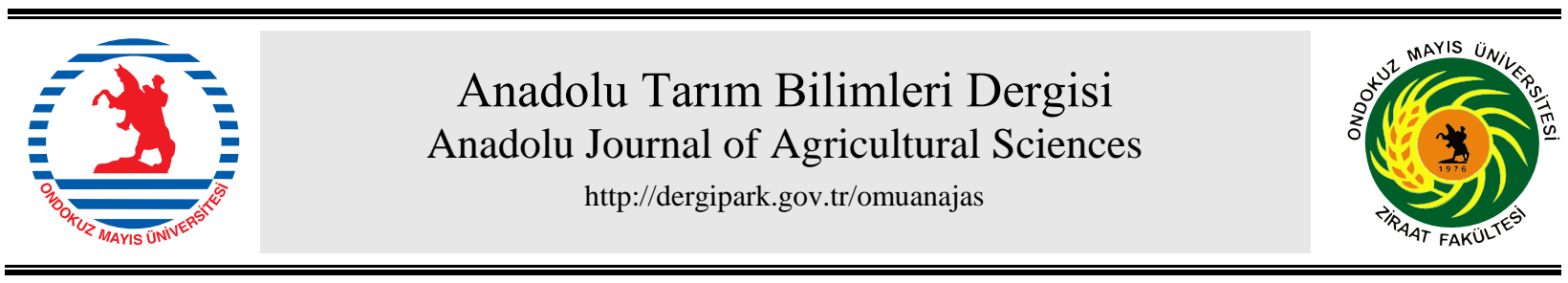

\title{
Araştırma/Research
}

Anadolu Tarım Bilim. Derg./Anadolu J Agr Sci, 36 (2021)

ISSN: $1308-8750$ (Print) 1308-8769 (Online) doi: 10.7161/omuanajas.949717

\section{Energy input-output analysis and technical efficiency of honey production in Turkey: A case study from Çanakkale province}

\author{
(D)Başak Aydın ${ }^{\mathrm{a}^{*}}$, (1) Duygu Aktürk ${ }^{\mathrm{b}}$ \\ ${ }^{a}$ Atatürk Soil Water and Agricultural Meteorology Research Institute, Kırklareli, Turkey \\ ${ }^{\mathrm{b}}$ Çanakkale 18 Mart University, Faculty of Agriculture, Department of Agricultural Economics, Çanakkale, Turkey
}

*Sorumlu yazar/corresponding author: basakaydin_1974@yahoo.com

Geliș/Received 08/06/2021 Kabul/Accepted 04/08/2021

\begin{abstract}
This study was carried out in order to determine the relationship between the energy inputs and yield and technical efficiency of honey production in Çanakkale province of Turkey. Data used in this study were obtained from 87 beekeepers using a face to face questionnaire method. The sample was selected according to stratified random sampling method. Stochastic frontier analysis was used in order to estimate the technical efficiency of honey production. According to the results, the energy use efficiency were found as $0.85,0.87$ and 1.08 in the groups, respectively. The distribution of the direct energy was lower than that of indirect energy and the highest energy inputs were provided by diesel fuel in all the groups. According to the efficiency analysis results, the technical efficiency scores were found as $0.74,0.78$ and 0.85 in the groups, respectively. Results of this study indicated that the inputs in the honey production were used more efficiently in the third group.
\end{abstract}

Türkiye'de bal üretiminde teknik etkinlik ve enerji girdi-çıktı analizi: Çanakkale ili örneği

ÖZET

Bu çalışma Türkiye'de Çanakkale ilinde bal üretiminde teknik etkinliği, enerji çıktı ve girdiler arasındaki ilişkiyi belirlemek amacıyla yürütülmüştür. Çalışmada kullanılan veriler 87 bal üreticisinden yüz yüze anket çalışması ile elde edilmiştir. Örnek seçimi tabakalı tesadüfi örnekleme yöntemiyle belirlenmiş olup, bal üretiminde teknik etkinlik Stokastik sınır analizi ile tespit edilmiştir. Elde edilen sonuçlara göre, enerji kullanım etkinliği gruplara göre sırasıyla $0.85,0.87$ ve 1.08 olarak bulunmuștur. Doğrudan enerjinin payı dolaylı enerjiye göre daha düşük olup, en yüksek enerji girdisi yakıt girdisi olarak belirlenmiştir. Etkinlik analizi sonuçlarına göre, teknik etkinlik skorları sırasıyla 0.74 , 0.78 ve 0.85 olarak bulunmuştur. Çalışma sonuçları bal üretiminde girdilerin üçüncü gruptaki işletmeler tarafından daha etkin kullanıldığını göstermektedir.
Keywords: Beekeeping Energy Honey Technical efficiency

Anahtar Kelimeler: Arıcilık Enerji

Bal

Teknik etkinlik 


\section{Introduction}

Beekeeping can be stated as producing living material such as swarm and queen bees and some products such as honey, royal jelly, pollen, bee venom and propolis by using bee, vegetative sources and labor and providing adequate pollination. Beekeeping has been a developing sector in Turkey as all over the World in recent years. Beekeeping has a significant influence on the economy of the country and it is prevalently performed in Turkey and in many countries (Sancak et al., 2013).

According to 2017 data, it was determined that total of 91 million of hives were present in the World and total of 1.861 .000 tons of honey was produced from these hives. In 2017, the honey import had been 685.000 tons by the increase of $6.4 \%$ and the honey export had been 690.000 tons by the increase of 9\%. India had the highest hive stock with the number of approximately 12.8 million hives. (Karaca and Özince, 2019).

Beekeeping is well developed in Turkey in terms of different climate and nature conditions, land structure, rich plant cover and genetic variability in honey bee population. Hive number, bee production amount, bees wax production amount and beekeeping enterprises number were 8.179.085, 104.077 tons, 3.765 tons and 82.862, respectively in Turkey in 2020 (Anonymous, 2021a).

When the climate of Çanakkale province is examined, it is observed that this province has the transition climate characteristics due to the geographical location. Generally, Çanakkale has the Mediterranean climate characteristics. The climate has affected the existence of the plant cover due to the soil conditions. For this reason, Çanakkale province is an appropriate nutrition area for the bees in terms of plant species and variety (Ilgar, 2018). Blossom honey is predominantly produced in the province besides the honeydew honey production. Domestic bee races are found in Gökçeada and around the Kaz Mountains. Biga, Central, Çan and Yenice districts come into prominence in beekeeping activities. Organic beekeeping activities are conducted in Gökçeada and Ezine districts (Anonymous, 2020). Total number of the hives was 83.854, total number of beekeeping enterprises was 1.506 and 1.716 .17 tons of honey and 83 tons of bees wax were produced in Çanakkale in 2020 (Anonymous, 2021).

Energy analysis of agricultural production is a significant approach for the definition and the classification of the agricultural systems in terms of energy consumption. In any agricultural production area, the ratio between the energy equivalent of the crop per unit area and the energy equivalent used for the production can be used as an indicator for a successful and profitable production and it is a significant value in terms of the efficient use of the energy (Topdemir, 2018).

Providing the efficiency in energy use by determining the production inputs for the sustainability of the production is regarded necessary. Within this scope, the analysis of energy use provides an opportunity to the production planners and policy implementers in order to evaluate the economic results of the energy use (Özkan et al., 2004).

Limited number of studies were conducted in order to determine the energy efficiency in honey production. Omidi-Arjenaki et al., (2016) determined investigated the energy use efficiency and performed an economic analysis of honey production in Iran. Bodescu et al., (2017) determined the energy use efficiency of honey production in lasi county, Romania. Adrian Moraru et al., (2020) determined the energy use of honey production in the Mountainous area of Romania.

The aims of this study were to investigate the effect of hive numbers on energy use pattern and determine the energy use efficiency of honey production in Çanakkale Province of Turkey. Besides, the technical efficiency of energy use in beekeeping enterprises was analyzed by means of the use of Stochastic Efficiency Frontier method.

\section{Materials and Methods}

This study was carried out in Çanakkale province of Turkey. The Çanakkale province is located in the northwest of Turkey, within $39^{\circ} 27^{\prime}$ and $40^{\circ} 45^{\prime}$ north latitude and $25^{\circ} 40^{\prime}$ and $27^{\circ} 30^{\prime}$ east longitude (Anonymous, 2021b).

The primary data in the study were composed of the data obtained from the beekeepers in Çanakkale province. Besides, the results of the previous studies were used in the study. The data including the hive number of the beekeepers were obtained from Çanakkale Beekeepers Union. Stratified sampling was done as the variation coefficient was high. The number of the beekeepers were divided into three strata, including 1-75 hives (first group), 76-150 hives (second group) and 151 hives and above (third group). The following formulas in Equation 1 were used in stratified random sampling method (Çiçek and Erkan, 1996).

$$
n=\frac{\mathbb{N} \Sigma\left[\mathbb{N}_{h}\left(S_{h}\right)^{2}\right]}{\mathbb{N}^{2} D^{2}+Z N_{h}\left(S_{h}\right)^{2}} \text { and } n_{i}=\frac{\mathbb{N}_{h}}{\Sigma N_{h}} * n
$$

$D^{2}=(d / Z)^{2}, d=$ deviation from average, $Z=$ degree of freedom, $N h=$ number of the enterprises in the strata, $S_{h}=$ Standard deviation of the strata, $\mathrm{S}_{\mathrm{h}}{ }^{2}=$ Variance of the strata, $\mathrm{ni}=$ sample number in the strata $\mathrm{n}=$ sample size 
The sample size was determined as 87 in 95\% confidence interval with 5\% sampling error margin. There were 27,38 and 22 surveyed beekeepers in the first, second and third groups, respectively.

The energy equivalents of the inputs and output are shown in Table 1. The inputs and the output were calculated per hive and then, they were multiplied by the coefficient of energy equivalent. According to the energy equivalents in Table 1, the energy use efficiency, energy productivity, specific energy and net energy, were calculated by using the formulas in Equation 2, 3, 4 and 5 (Mohammadi et al., 2008):

$$
\begin{aligned}
& \text { Energy use eff iciency }=\frac{\text { Energy output }\left(M J \alpha^{-1}\right)}{\text { Energy input }\left(M J h \alpha^{-1}\right)} \\
& \text { Specific energy }=\frac{\text { Energy input }\left(M \mathrm{MJ}^{-1}\right)}{\text { Field }(\mathrm{kg} \text { hive }} \\
& \text { Energy productivity }=\frac{\text { Yield }\left(\mathrm{kg} \mathrm{hive}^{-1}\right)}{\text { Energy input }\left(M \mathrm{~h}^{\mathrm{h}} \alpha^{-1}\right)}
\end{aligned}
$$

$$
\begin{aligned}
& \text { Net energy } \left.=\text { Energy output }(M] a^{-1}\right)- \\
& \text { Energy input }\left(M \mathrm{ha}^{-1}\right)
\end{aligned}
$$

Input energy was divided into direct and indirect, renewable and non-renewable energy forms. Direct energy included human labor, drug and sugar while the indirect energy included energy spent in transportation (through tracks) and fuel. Human labor was considered as renewable energy and fuel, sugar, drug and track were considered as the non-renewable energy (Omidi-Arjenaki et al., 2016).

Technical efficiency of honey production in terms of energy use was determined by stochastic efficiency frontier approach. Stochastic efficiency frontier approach was developed by Aigner et al., (1977), Meeusen and Broeck (1977) and Battese and Corra (1977)] in order to estimate the efficiency in the production by using the production function which was stated as $\mathrm{Yi}=\mathrm{xi} \beta+$ ei. Stochastic efficiency frontier is a parametric method which is used for the estimation of the efficiency.

Aigner et al., (1977) and Meeusen and Broeck (1977) stated that the error term (عi) consisted of two independent components and formulated the production function by using Equation 6 and 7.

$$
\begin{gathered}
\mathrm{Yi}=\mathrm{xi} \beta+\text { vi }- \text { ui }(\mathrm{i}: 1,2, \ldots, \mathrm{n}) \\
\text { vi }- \text { ui }=\varepsilon
\end{gathered}
$$

Yi indicates the production function of the enterprise, $x i$ indicates the input vector of the firm and $\beta$ indicates the coefficient. vi is a random variable independent from ui and it is uncontrolled and normally distributed $\mathrm{N}\left(0, \sigma_{\mathrm{v}}^{2}\right)$ variable. ui is a nonnegative, partially controlled and consequently, it is an independent random variable which causes the technical inefficiency. ui shows a semi normal, discrete normal or exponential distribution depending on the function. Battese and Coelli (1995) developed the following model for the explanation of the changes in ui which reflects the technical inefficiency.

$$
\text { ui }=\text { zi } \delta
$$

In Equation 8, zi indicates the variables (education, age,) which represents the specific characteristics affecting

\begin{tabular}{|c|c|c|}
\hline Input/output & Energy equivalent (MJ unit ${ }^{-1}$ ) & References \\
\hline \multicolumn{3}{|l|}{ Inputs } \\
\hline Labor (h) & 1.96 & (Mandal et al., 2002; Singh, 2002) \\
\hline Fuel (1) & 56.31 & (Singh, 2002). \\
\hline Track (km ton) & 10.15 & (Omidi-Arjenaki et al., 2016) \\
\hline Drug (kg) & 13.64 & (Omidi-Arjenaki et al., 2016) \\
\hline Sugar (kg) & 15.40 & (Omidi-Arjenaki et al., 2016) \\
\hline \multicolumn{3}{|l|}{ Output } \\
\hline Honey $(\mathrm{kg})$ & 12.72 & (Omidi-Arjenaki et al., 2016) \\
\hline
\end{tabular}
the technical efficiency and $\delta$ indicates the coefficients. The efficiency of an enterprise by stochastic efficiency frontier approach is determined as the ratio of the observed output to the estimated ratio by using equation 6 . In this study, technical efficiency was estimated by using the maximum likelihood method and Cobb-Douglas function which has a discrete normal distribution and developed by Battase and Coelli (1995). Stochastic efficiency frontier estimations were done by using FRONTIER 4.1, developed by Coelli (2007).

Table 1. Energy equivalent coefficients of the inputs and the outputs in honey production Çizelge 1. Bal üretiminde kullanılan girdilerin ve çıktıların enerji eşdeğeri katsayıları 


\section{Results and Discussion}

\subsection{Analysis of energy use in honey production}

The amounts of inputs used in honey production and the output per hive are given in Table 2. According to the average of the enterprises, around $7.83 \mathrm{~h}$ human labor, 2.081 diesel fuel, $2.55 \mathrm{~km}$ ton track, $0.50 \mathrm{~kg}$ drug and 3.93 $\mathrm{kg}$ sugar were used to produce honey. The average honey yield was found as 15.78, 14.98 and 18.97 in the groups, respectively. The honey yield was found as $16.24 \mathrm{~kg}$ per hive according to the average of the enterprises. Onuç et al., (2019) calculated the average honey yield per hive as $19.27 \mathrm{~kg}$ in their study.

Table 2. Amounts of inputs and outputs of honey production Çizelge 2. Bal üretiminde girdilerin ve çıtıtıların miktarları

\begin{tabular}{lrrrr}
\hline Inputs (unit) & 1.group & 2.group & 3.group & Average \\
\hline Labor (h) & 11.34 & 6.80 & 5.29 & 7.83 \\
Fuel (l) & 2.06 & 2.15 & 1.98 & 2.08 \\
Track (km ton) & 4.23 & 1.69 & 1.96 & 2.55 \\
Drug (kg) & 0.59 & 0.43 & 0.52 & 0.50 \\
Sugar (kg) & 3.00 & 4.02 & 4.91 & 3.93 \\
\hline Output & & & & \\
\hline Honey (kg) & 15.78 & 14.98 & 18.97 & 16.24 \\
\hline
\end{tabular}

The energy equivalent of the output and the inputs are given in Table 3. The total energy input was calculated as 225.72 $\mathrm{MJ}_{\text {hive }}{ }^{-1}$ according to the average of the enterprises and it consisted of 51.91\% diesel fuel, $26.80 \%$ sugar, $11.44 \%$ track, $6.80 \%$ labor and $3.04 \%$ drug. The highest energy input was found as diesel fuel and it was followed by sugar and track in all of the groups. In the study of Omidi-Arjenaki et al. (2016), the energy input of sugar in honey production represented the highest share of the total energy inputs, and it was followed by electricity and track inputs, respectively. Adrian Moraru et al., (2020) determined that the shares held in the total of the energy input were $40.30 \%$ for fuel, $32.70 \%$ for sugar, $21.60 \%$ for track, $4.70 \%$ for human labor, $0.62 \%$ electricity and $0.07 \%$ drugs.

The energy use efficiency values were found as 0.85 and 0.87 in the first and second groups, respectively, showing the inefficiency in the energy use in honey production. This parameter was found as 1.08 in the third group and this indicated the efficiency in the use of energy in the enterprises in the third group. The energy use efficiency was found as 0.91 according to the average of the enterprises (Table 4). In literature, the energy use efficiency values in honey production were found as 0.54 (Omidi-Arjenaki et al., 2016), 0.38 (Bodescu et al., 2017) and 0.47 (Adrian Moraru et al., 2020).

The energy productivity values were found as $0.07 \mathrm{~kg} \mathrm{MJ}^{-1}$ in the first and second groups and $0.08 \mathrm{~kg} \mathrm{MJ}^{-1}$ in the third group. The enterprises in the third group can produce $0.01 \mathrm{~kg}$ of more output than the other groups.

According to the average of the enterprises, the specific energy was found as $13.90 \mathrm{MJ} \mathrm{kg}^{-1}$. In other words, this meant that for each kilogram of honey produced, about $13.90 \mathrm{MJ}$ of energy was consumed.

The net energy was negative in the first and second groups and it was calculated as $16.98 \mathrm{MJ}$ in the third group. Therefore, it can be concluded that energy was being lost in honey production and there was not high efficiency in usage of energy in the first and second groups.

Most of the total energy inputs were depended on the indirect form in all the groups. Whereas, the ratio of the indirect energy was lower in the third group $(58.52 \%)$ than the other groups. According to the average of the enterprises, the ratio of the direct energy form was $36.64 \%$ whereas the ratio of the indirect energy form was $63.36 \%$. This result was similar with the result of Adrian-Moraru et al., (2020) and they found that from the total inputs, direct inputs accounted for $38.1 \%$. 
Table 3. Energy equivalents of inputs and outputs for honey production (MJ hive $\mathrm{C}^{-1}$ )

Çizelge 3. Bal üretiminde girdilerin ve çıtıtıların enerji eşdeğerleri

\begin{tabular}{|c|c|c|c|c|c|c|c|c|}
\hline \multirow[b]{2}{*}{ Inputs } & \multicolumn{2}{|c|}{ 1.group } & \multicolumn{2}{|c|}{ 2.group } & \multicolumn{2}{|c|}{ 3.group } & \multicolumn{2}{|c|}{ Average } \\
\hline & $\begin{array}{l}\text { Energy } \\
\text { equivalent }\end{array}$ & $\%$ & $\begin{array}{c}\text { Energy } \\
\text { equivalent }\end{array}$ & $\%$ & $\begin{array}{l}\text { Energy } \\
\text { equivalent }\end{array}$ & $\%$ & $\begin{array}{c}\text { Energy } \\
\text { equivalent }\end{array}$ & $\%$ \\
\hline Labor & 22.23 & 9.44 & 13.32 & 6.07 & 10.37 & 4.62 & 15.34 & 6.80 \\
\hline Fuel & 116.06 & 49.29 & 121.33 & 55.26 & 111.38 & 49.65 & 117.18 & 51.91 \\
\hline Track & 42.92 & 18.23 & 17.11 & 7.79 & 19.90 & 8.87 & 25.83 & 11.44 \\
\hline Drug & 8.10 & 3.44 & 5.86 & 2.67 & 7.10 & 3.16 & 6.87 & 3.04 \\
\hline Sugar & 46.17 & 19.61 & 61.95 & 28.21 & 75.58 & 33.69 & 60.50 & 26.80 \\
\hline Total & 235.48 & 100.00 & 219.57 & 100.00 & 224.33 & 100.00 & 225.72 & 100.00 \\
\hline \multicolumn{9}{|l|}{ Output } \\
\hline Honey & \multicolumn{2}{|c|}{200.72} & \multicolumn{2}{|c|}{190.50} & \multicolumn{2}{|c|}{241.31} & \multicolumn{2}{|c|}{206.52} \\
\hline
\end{tabular}

The results indicated that the current energy use pattern among the enterprises was based on nonrenewable energy in the honey production. As seen from Table 4, on average, the non-renewable form of energy input was $93.20 \%$ of the total energy input compared to $6.80 \%$ for the renewable form. This indicated that honey production depended mainly on fossil fuels and sugar. In previous studies, Bodescu et al. (2017) determined that the renewable input represented 5.3\% of total inputs and Adrian Moraru et al., (2020) found that the ratio of the renewable inputs in total energy input was $5.1 \%$ in honey production (Table 4 ).

Table 4. Energy parameters in honey production.

Çizelge 4. Bal üretiminde enerji parametreleri

\begin{tabular}{|c|c|c|c|c|}
\hline Parameters & 1.group & 2.group & 3.group & Average \\
\hline Energy use efficiency & 0.85 & 0.87 & 1.08 & 0.91 \\
\hline Energy productivity $\left(\mathrm{kg} \mathrm{MJ}^{-1}\right)$ & 0.07 & 0.07 & 0.08 & 0.07 \\
\hline Specific energy $\left(\mathrm{MJ} \mathrm{kg}^{-1}\right)$ & 14.92 & 14.66 & 11.82 & 13.90 \\
\hline Net energy (MJ hive ${ }^{-1}$ ) & -34.76 & -29.08 & 16.98 & -19.20 \\
\hline Direct energy (MJ hive $\left.{ }^{-1}\right)$ & $76.50(32.49 \%)$ & $81.13(36.95 \%)$ & $93.05(41.48 \%)$ & $82.71(36.64 \%)$ \\
\hline Indirect energy (MJ hive $\left.{ }^{-1}\right)$ & 158.98 & 138.44 & 131.28 & 143.01 \\
\hline marect energy (IMJ nive ) & $(67.51 \%)$ & $(63.05 \%)$ & $58.52 \%)$ & $(63.36 \%)$ \\
\hline Renewable energy (MJ hive ${ }^{-1}$ ) & $22.23(9.44 \%)$ & $13.32(6.07 \%)$ & $10.37(4.62 \%)$ & $15.34(6.80 \%)$ \\
\hline Non_renewable eneroy $\left(\mathrm{MI} \mathrm{hive}^{-1}\right.$ ) & 213.25 & 206.25 & 213.96 & 210.38 \\
\hline Non-renewable energy (IMJ nive) & $(90.56 \%)$ & $(93.93 \%)$ & $(95.38 \%)$ & $(93.20 \%)$ \\
\hline Total energy input $\left(\mathrm{MJ} \mathrm{hive}^{-1}\right)$ & $235.48(100 \%)$ & $219.57(100 \%)$ & $224.33(100 \%)$ & $225.72(100 \%)$ \\
\hline
\end{tabular}

\subsection{Modeling and technical efficiency of honey production}

In stochastic frontier model, energy equivalent of the honey yield (MJ hive ${ }^{-1}$ ) was used as output. The inputs in order to obtain the output were determined as labor $\left(\mathrm{MJ} \mathrm{hive}^{-1}\right)$, fuel $\left(\mathrm{MJ} \mathrm{hive}^{-1}\right)$, track $\left(\mathrm{MJ}\right.$ hive $\left.\mathrm{e}^{-1}\right)$, drug $\left(\mathrm{MJ} \mathrm{hive}^{-1}\right)$ and sugar $\left(\mathrm{MJ} \mathrm{hive}^{-1}\right)$. The specific variables of the beekeepers which could affect the technical inefficiency were selected as producer's age (year), education period (year), family size (person), beekeeping experience (year) and dealing with an agricultural activity besides beekeeping (yes 1 , no 0 ). The descriptive statistics of these variables are given in Table 5.

Stochastic Cobb-Douglas frontier analysis results of the model are shown in Table 6. The variance parameters of the model in all groups were statistically significant. The gamma values were determined as $99 \%, 48 \%$ and $42 \%$, respectively for the groups. The highest gamma value was observed in the first group and this result indicated that the variation in the output value resulted from the input usage inefficiency in the ratio of $99 \%$. High gamma value indicated that there was an inefficiency problem in the enterprises and this caused variations in the output amount.

The total of the coefficients of the variables were found as $1.484,-0.617$ and 0.619 in the groups, respectively. According to the results, it was concluded that the enterprises in the first group had increasing return to scale whereas the enterprises in the second and third groups had decreasing return to scale. It was determined that an increase of $\% 1.48$ in the output amount would occur when the enterprises increased the input amounts in the ratio of $1 \%$ in the first group. In the second and third groups, it was determined that when the enterprises increased the input amounts in the ratio of $1 \%$, the output amounts would decrease in the ratio of approximately $0.62 \%$, respectively. 
Table 5. Descriptive statistics of the variables in stochastic frontier model

Çizelge 5. Stokastik sınır analizinde kullanılan değisşkenlerin tanımlayıcı istatistikleri

\begin{tabular}{|c|c|c|c|c|c|c|}
\hline & \multicolumn{2}{|c|}{ 1.group } & \multicolumn{2}{|c|}{ 2.group } & \multicolumn{2}{|c|}{ 3.group } \\
\hline & Average & SD & Average & SD & Average & SD \\
\hline \multicolumn{7}{|l|}{ Output } \\
\hline Yield (MJ hive ${ }^{-1}$ ) & 200.72 & 100.57 & 190.50 & 93.53 & 241.31 & 94.88 \\
\hline \multicolumn{7}{|l|}{ Production function variables } \\
\hline Labor (MJ hive $\left.{ }^{-1}\right)$ & 22.23 & 20.58 & 13.32 & 7.74 & 10.37 & 4.78 \\
\hline Fuel $\left(\mathrm{MJ}\right.$ hive $\left.^{-1}\right)$ & 116.06 & 59.45 & 121.33 & 68.10 & 111.38 & 65.94 \\
\hline Track (MJ hive $\left.{ }^{-1}\right)$ & 42.92 & 56.05 & 17.11 & 14.98 & 19.90 & 16.78 \\
\hline Drug (MJ hive ${ }^{-1}$ ) & 8.10 & 1.82 & 5.86 & 1.26 & 7.10 & 2.10 \\
\hline Sugar $\left(\mathrm{MJ} \mathrm{hive}^{-1}\right)$ & 46.17 & 32.30 & 61.95 & 30.62 & 75.58 & 47.09 \\
\hline \multicolumn{7}{|l|}{ Explanatory variables } \\
\hline Age (year) & 57.07 & 10.67 & 54.24 & 10.14 & 52.64 & 11.39 \\
\hline Education period (year) & 8.56 & 3.71 & 10.08 & 4.15 & 8.77 & 4.14 \\
\hline Family size (person) & 3.00 & 1.00 & 3.05 & 1.01 & 3.00 & 0.98 \\
\hline Experience in beekeeping (year) & 17.67 & 10.49 & 18.34 & 8.52 & 23.23 & 10.82 \\
\hline Agricultural activity (\%) & 0.19 & 0.40 & 0.13 & 0.34 & 0.36 & 0.49 \\
\hline
\end{tabular}

SD: Standard deviation

It was observed that the effect of the labor variable on the output was positive in the first and third groups whereas it was negative in the second group. The labor variable was statistically significant in the first and second groups. An increase in the ratio of $1 \%$ in labor use would cause an increase in the ratio of $\% 0.15$ in the first group whereas it would cause a decrease in the ratio of $0.33 \%$ in the second group.

When the effect of fuel use on honey yield was examined, it was determined that the effect of this variable was positive in the third group and negative in other groups.

The coefficients of fuel variable were not statistically significant in the second and third groups. It was concluded that by adding $1 \%$ of fuel consumption, the honey production would decrease in the ratio of $0.35 \%$.

Track variable coefficient was statistically significant in the first and second groups and produced a positive effect. It was concluded that by increasing $1 \%$ of track consumption, the honey production would increase $0.17 \%$ and $0.16 \%$ in these groups, respectively.

Drug use variable produced a positive effect in the first and third groups and negative effect in the second group and this variable was statistically significant only in the first group. It was determined that an increase in the ratio of $1 \%$ in drug use would cause an increase in the ratio of $\% 1.28$ in the enterprises in the first group.

The sugar use variable, one of the main inputs in honey production, was statistically significant for the all groups. This coefficient of this variable was positive in the first and third groups while it was negative in the second group. By increasing $1 \%$ of sugar consumption, the honey production would increase $0.24 \%$ in the first group and $0.20 \%$ in the third group whereas it would decrease $0.18 \%$ in the second group.

Omidi-Arjenaki et al., (2016) determined that the honey production increased $0.52 \%$ and $0.48 \%$, respectively by adding $1 \%$ of sugar or fuel consumption,

Producer's age affected the technical inefficiency negatively in all the groups and it was statistically significant only in the third group. It was determined that as the producers' ages increased, the technical inefficiency would decrease in the third group.

Producer's education period affected the technical inefficiency negatively in the first and second groups and positively in the third group. This variable was statistically significant in the first and third groups. It was determined that the efficiency performance of the producers would increase as the education period of the producers increased in the first group.

Family size variable affected the technical inefficiency positively in the first and second groups and negatively in the third group. This variable was not statistically significant in the groups.

Experience in beekeeping variable affected the technical inefficiency negatively as expected in all the groups and it was statistically significant in the first and second groups. It was concluded that the technical efficiency of the beekeepers in the first and second groups would increase as the beekeeping experiences of the producers increased.

The coefficient of dealing with an agricultural activity besides beekeeping variable was negative in the first and third groups whereas it was positive in the second group. This variable was statistically significant in the first and third groups. Dealing with an agricultural activity besides beekeeping affected the technical efficiency positively in 
these groups. This result can be interpreted as the producers, dealing with agricultural activities, are informed about the developments in agriculture and this can have a positive effect on technical efficiency (Table 6).

Table 6. Estimated parameters for frontier and inefficiency models

Çizelge 6. Frontier ve etkinsizlik modelinde parameter tahminleri

\begin{tabular}{|c|c|c|c|c|c|c|c|}
\hline \multirow{2}{*}{ Variables } & \multirow{2}{*}{ Parameter } & \multicolumn{2}{|c|}{ 1.group } & \multicolumn{2}{|c|}{ 2.group } & \multicolumn{2}{|c|}{ 3.group } \\
\hline & & Coefficient & S.E. & Coefficient & S.E. & Coefficient & S.E. \\
\hline \multicolumn{8}{|c|}{ Stochastic frontier analysis } \\
\hline Constant & $\beta_{0}$ & $3.069 * * *$ & 0.715 & $7.132 * * *$ & 0.833 & $3.744 * * *$ & 0.857 \\
\hline Ln (Labor) & $\beta_{1}$ & $0.150 *$ & 0.078 & $-0.329 * * *$ & 0.099 & 0.016 & 0.167 \\
\hline Ln (Fuel) & $\beta_{2}$ & $-0.352 *$ & 0.203 & -0.068 & 0.047 & 0.095 & 0.147 \\
\hline Ln (Track) & $\beta_{3}$ & $0.167 * *$ & 0.086 & $0.161 * * *$ & 0.061 & -0.043 & 0.076 \\
\hline Ln (Drug) & $\beta_{4}$ & $1.282 * * *$ & 0.126 & -0.198 & 0.331 & 0.355 & 0.312 \\
\hline Ln (Sugar) & $\beta_{5}$ & $0.237 * * *$ & 0.078 & $-0.183 * *$ & 0.076 & $0.196^{*}$ & 0.104 \\
\hline Return to scale & & 1.484 & & -0.617 & & 0.619 & \\
\hline \multicolumn{8}{|c|}{ Technical inefficiency model } \\
\hline Constant & $\delta_{0}$ & 0.089 & 0.997 & 0.988 & 1.159 & $-2.398 * *$ & $1.175^{* *}$ \\
\hline Age & $\delta_{1}$ & 0.011 & 0.017 & 0.021 & 0.020 & $0.029 *$ & 0.017 \\
\hline Education period & $\delta_{2}$ & $-0.711 * *$ & 0.298 & -0.036 & 0.041 & $0.152 * *$ & 0.064 \\
\hline Family size & $\delta_{3}$ & 0.228 & 0.171 & 0.613 & 0.188 & -0.141 & 0.176 \\
\hline Beekeeping experience & $\delta_{4}$ & $-0.036^{*}$ & 0.021 & $-0.119 * * *$ & 0.034 & -0.005 & 0.017 \\
\hline Agricultural activity & $\delta_{5}$ & $-1.111 *$ & 0.669 & 0.030 & 0.323 & $-1.033 * *$ & 0.504 \\
\hline \multicolumn{8}{|l|}{ Variance parameters } \\
\hline Sigma square & $\sigma^{2}$ & $0.535^{* *}$ & 0.218 & $0.133 * *$ & 0.058 & $0.106 * * *$ & 0.040 \\
\hline Gamma & $\gamma$ & $0.999 * * *$ & 0.00003 & $0.476^{*}$ & 0.266 & 0.424 & 0.325 \\
\hline \multirow{2}{*}{\multicolumn{2}{|c|}{$\begin{array}{l}\text { Log likelihood function } \\
\text { Log likelihood function (LR) test }\end{array}$}} & \multicolumn{2}{|c|}{1.552} & \multicolumn{2}{|c|}{-9.681} & \multicolumn{2}{|c|}{-1.889} \\
\hline & & 33.739 & & $24.842^{-}$ & & 10.11 & \\
\hline \multicolumn{8}{|c|}{ Technical efficiency } \\
\hline \multirow{2}{*}{\multicolumn{2}{|c|}{$\begin{array}{l}\text { Average } \\
\text { Standard deviation }\end{array}$}} & \multicolumn{2}{|c|}{0.74} & \multicolumn{2}{|c|}{0.78} & \multicolumn{2}{|c|}{0.85} \\
\hline & & \multicolumn{2}{|c|}{0.28} & \multicolumn{2}{|c|}{0.21} & \multicolumn{2}{|c|}{0.18} \\
\hline \multicolumn{2}{|l|}{ Minimum } & \multicolumn{2}{|c|}{0.24} & \multicolumn{2}{|c|}{0.26} & \multicolumn{2}{|c|}{0.37} \\
\hline Maximum & & \multicolumn{2}{|c|}{0.99} & \multicolumn{2}{|c|}{0.98} & \multicolumn{2}{|c|}{0.98} \\
\hline
\end{tabular}

*: Significant at $10 \%$ significance level; **: Significant at 5\% significance level; ***: Significant at $1 \%$ significance level; S.E.: Standard error

Distribution of the efficiency scores in the groups were given in Figure 1,2 and 3. According to the efficiency analysis results, the technical efficiency scores in the first group were determined to change between 0.24 and 0.99 and the average technical efficiency coefficient was found as 0.74 . This result indicated that the producers could obtain $74 \%$ of the maximum honey yield by keeping the input levels. Besides, it was concluded that the technical efficiency of $25.95 \%$ of the enterprises was under $50 \%$ and the technical efficiency coefficients of $40.74 \%$ of the enterprises were between 0.96 and 1 (Figure 1).

The technical efficiency was determined to change between 0.26 and 0.98 in the second group and the average technical efficiency coefficient was found as 0.78 . It was concluded that the enterprises in this group would be able to reach full efficiency level due to the decrease in the ratio of $22 \%$ in the input amounts as long as they would keep the output amounts (Figure 2).

The technical efficiency scores in the third group changed between 0.37 and 0.98 and it was found as 0.85 on average. The enterprises in this group would be able to reach full efficiency level due to the decrease in the ratio of $15 \%$ in the input amounts as long as they would keep the output amounts (Figure 3). 


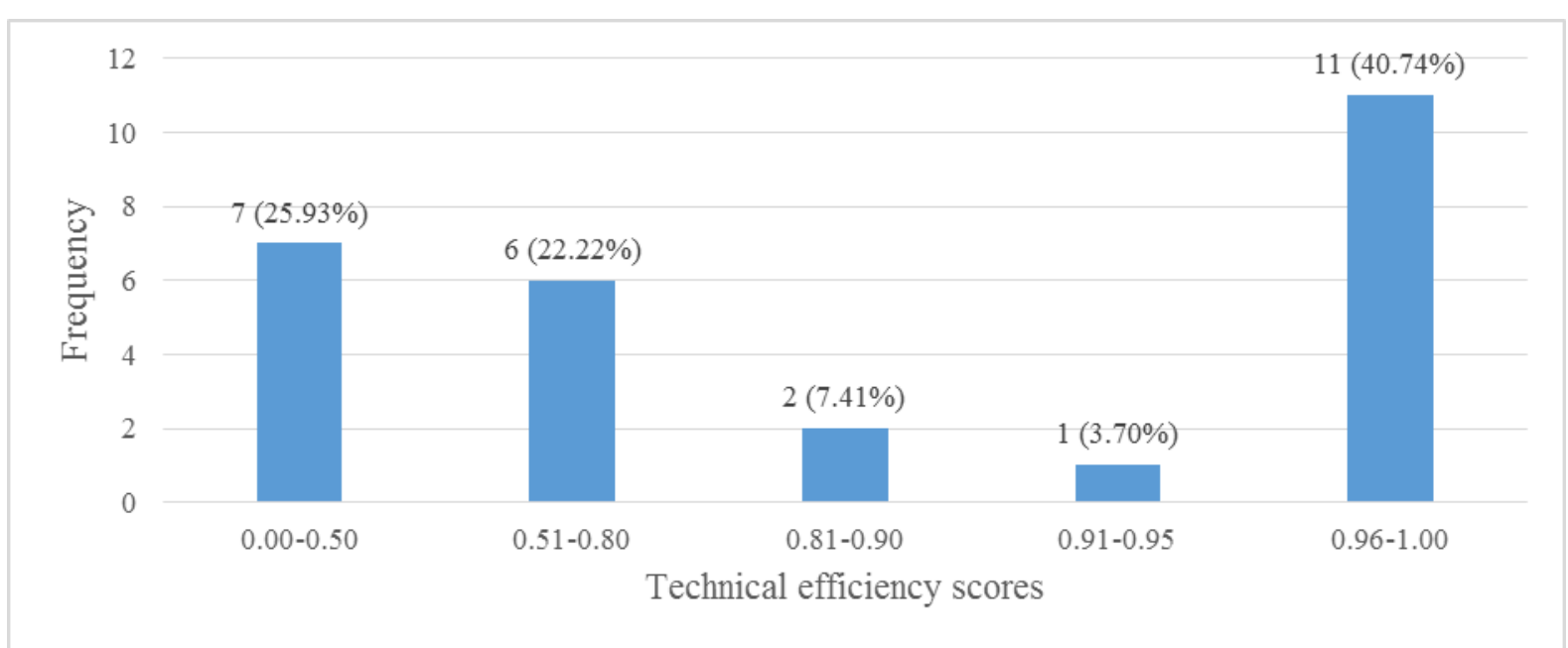

Figure 1. Distribution of the efficiency scores in the first group.

Şekil 1. Birinci grupta etkinlik skorlarının dăğlımı.

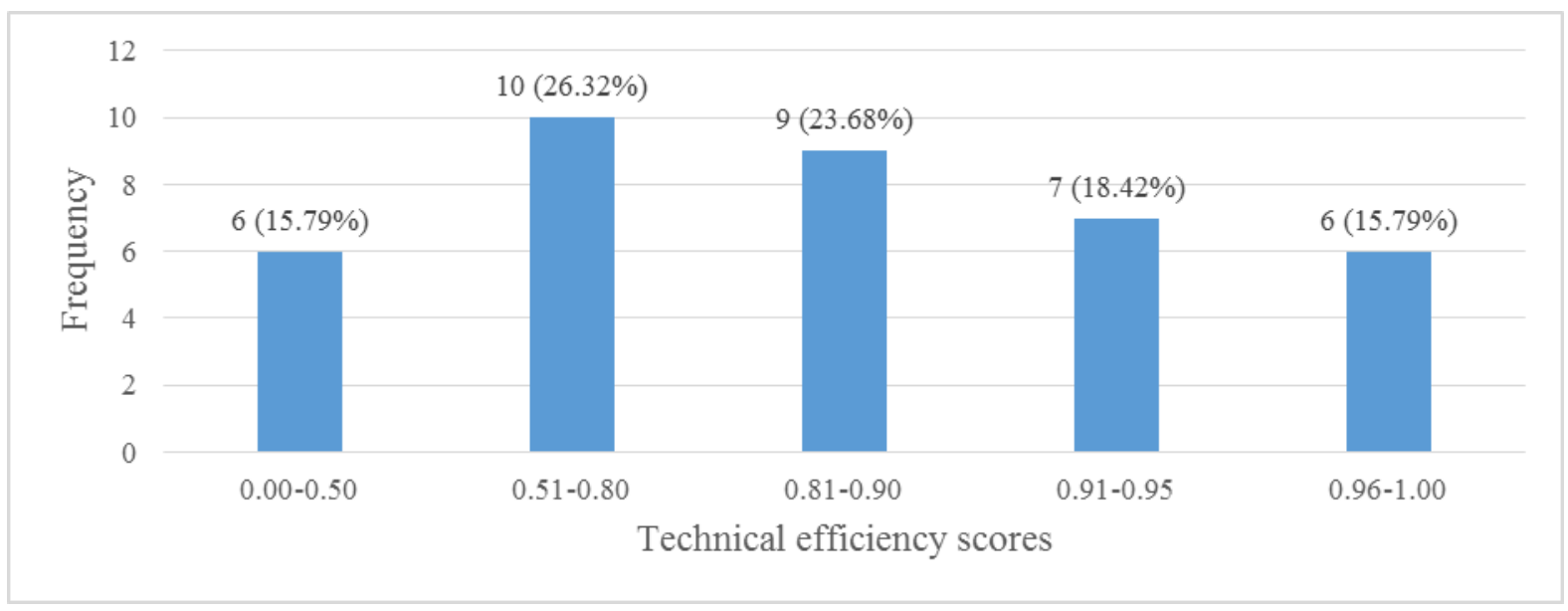

Figure 2. Distribution of the efficiency scores in the second group.

Şekil 2. İkinci grupta etkinlik skorlarının dağıllımı.

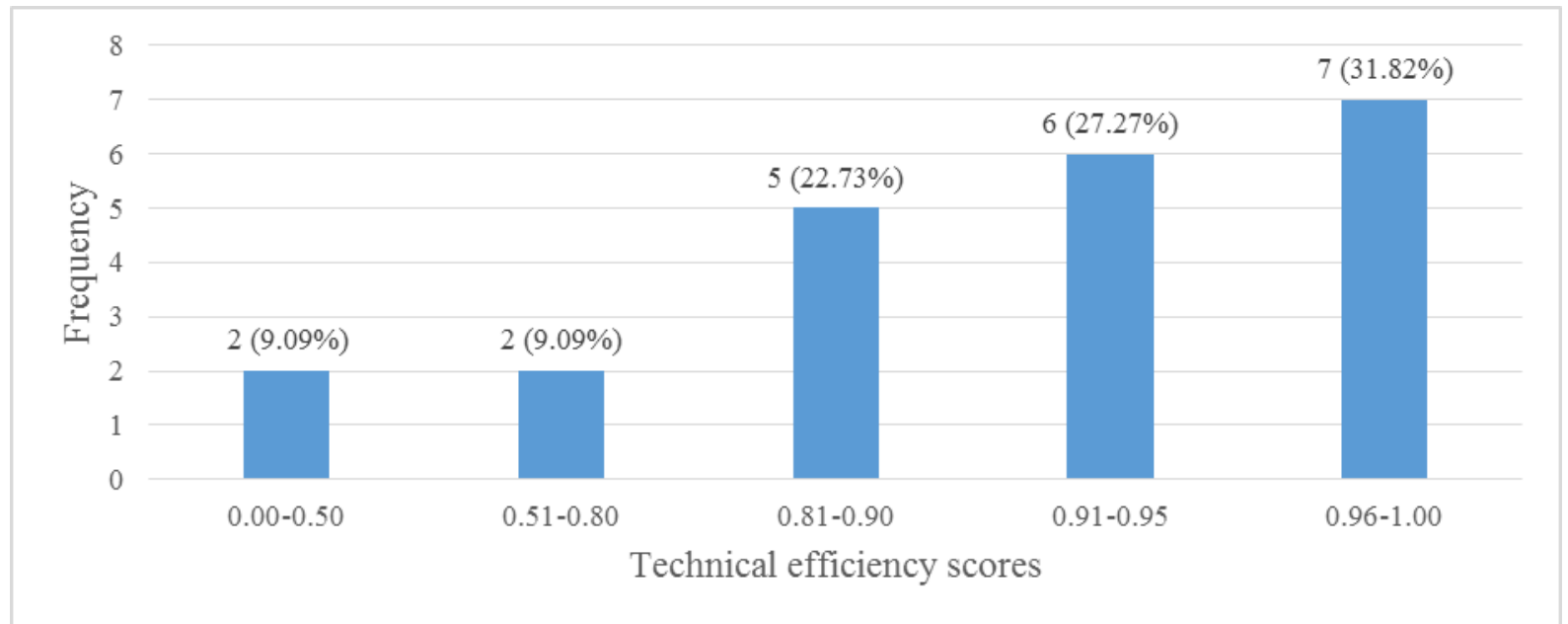

Figure 3. Distribution of the efficiency scores in the third group

Şekil 3. Üçüncü grupta etkinlik skorlarının dağılımı. 


\section{Conclusion}

In this study, energy use and technical efficiency of honey production in Çanakkale province were determined. Energy use efficiency of the honey production in the enterprises in the third group was calculated as 1.08. The energy use efficiency value was under 1 in the first and second groups and this indicated that the inputs were not used efficiently. Inefficient use of the inputs causes some problems. Unconscious use of pesticide, fuel and sugar causes wastage and pollutes the environment. For this reason, the beekeepers should be trained in terms of input usage in honey production. Nutrition of the bees with unnatural sugars is not applicable in terms of the health of the bees and the quality of the honey. In this respect, the beekeepers should be trained on this subject and the organic sugar facilities should be promoted.

Fuel had the highest share on energy use for honey production and it should be reduced to provide optimum energy consumption. Also, the results of econometric model showed the necessity of the use of fuel on yield, especially in the first group. The use of this input needs an adequate management for economical honey yield level with lower energy consumption.

Renewable energy sources are unlimited sources and do not damage the nature. On average, the non-renewable form of energy input was found as $93.20 \%$, indicating that honey production depended mainly on fossil fuels and sugar in the research area.

It was concluded that the beekeepers performed more efficient production in the third group. The producers in the first and second groups should be trained in terms of input usage in the production. Besides, it was determined that the beekeepers having 151 hives and above used the inputs more efficient. In this case, it can be said that increase of the hive number will have a positive effect on the increase of the efficiency.

In order to decrease the negative climate condition effects, the beekeepers should be promoted for insurance and besides, the insurance premium ratio should be increased. The support amount per hive should be increased and supports should be provided for beeswax, royal jelly, bee venom.

Migratory beekeeping is performed in Çanakkale province. In migratory beekeeping, inputs are used in the transportation to the stopovers for the honey production and low interest loan can be supplied for these inputs. Besides, underpricing can be provided to the beekeepers who are registered to the cooperatives and the unions on purchasing sugar used in feeding.

\section{References}

Adrian Moraru, R., Bodescu, D., Magdici, M., Simeanu, D., Bulgariu, E., 2020. Analysis of the energy input-output of honey production in the mountainous area of Romania. Environmental Engineering and Management Journal, 18(11): 2429-2440. doi:10.30638/eemj.2019.231.

Aigner, D.J., Lovell, C.A.K., Schmidt, P. 1977. Formulation and estimation of stochastic frontier production function models. Journal of Econometrics, 6(1): 21-31. doi:10.1016/0304-4076(77)90052-5.

Anonymous, 2020. Çanakkale tarım ve hayvancılık yatırım rehberi. Güney Marmara Kalkınma Ajansı, Çanakkale.

Anonymous, 2021a. İstatistik göstergeler. Available at http://www.tuik.gov.tr. Access date: 10.05.2021.

Anonymous, 2021b. Available at https://canakkale.ktb.gov.tr/TR-70467/cografya.html Access date: 30.06.2021.

Bodescu, D., Ştefan, G., Adrian Moraru, R., Coca, O., Brumă, S., Doliş, M.G., 2017. Input-output energy analysis of honey production in Iaşi County, Romania. 30th IBIMA Conference, 8-9 November, Madrid, Spain.

Battese, G.E., Corra, G.S., 1977. Estimation of a production frontier model with application to the pastoral zone of Eastern Australia. Australian Journal of Agricultural Economics, 21(03): 169-179. doi:10.1111/j.14678489.1977.tb00204.x.

Battese, G. E., Coelli, T.J., 1995. A model for technical inefficiency effects in a stochastic frontier production function for panel data. Empirical Economics, 20(2): 325-332. doi:10.1007/BF01205442.

Coelli, T. A., 2007. Guide to frontier version 4.1: A computer program for stochastic frontier production and cost function estimation. CEPA, Armidale, Australia.

Çiçek, A., Erkan, O., 1996. Tarım ekonomisinde araştırma örnekleme yöntemleri. Gaziosmanpaşa Üniversitesi, Ziraat Fakültesi Yayınları No: 12, Tokat.

Ilgar R., 2018. Beekeeping activities in Çanakkale Province. Turkish Studies, 13(26): 713-724. doi:10.7827/TurkishStudies.14134.

Karaca, N., Özince, G., 2019. Ardahan arıcılık sektörü mevcut durum analizi ve stratejik eylem planı. ISBN: 978605-68045-5-7. Serhat Kalkınma Ajans1.

Mandal, K.G., Saha, K.P., Gosh, P.L., Hati, K.M., Bandyopadhyay, K.K., 2002. Bioenergy and economic analyses of soybean based crop production systems in central India. Biomass \& Bioenergy, 23(5): 337-345. doi:10.1016/S0961-9534(02)00058-2.

Meeusen, W., Van den Broeck, J., 1977. Efficiency estimation from cobb-douglas production functions with composed error. International Economic Review, 18(2): 435-444. doi:10.2307/2525757 
Mohammadi, A., Tabatabaeefar, A., Shahin, S., Rafiee, S., Keyhani, A., 2008. Energy use and economical analysis of potato production in Iran a case study: Ardabil province. Energy Conversion and Management, 49(12): 35663570. doi:10.1016/j.enconman.2008.07.003

Omidi-Arjenaki, O., Ebrahimi, R., Ghanbarian, D., 2016. Analysis of energy input and output for honey production in Iran (2012-2013). Renewable and Sustainable Energy Reviews, 59(2016): 952-957. doi:10.1016/j.rser.2016.01.060.

Onuç, Z., Yanar, A., Saner, G., Güler, D., 2019. An analysis of economical aspect of the beekeeping enterprise: a case of Kemalpaşa district-İzmir/Turkey. Ege Üniversitesi Ziraat Fakültesi Dergisi, 56(1): 7-17. doi:10.20289/zfdergi.420370

Özkan, B., Akcaoz, H., Fert, C., 2004. Energy input-output analysis in Turkish agriculture. Renewable Energy, 29(1): 39-51. doi:10.1016/S0960-1481(03)00135-6

Sancak, K., Zan Sancak, A., Aygören, E., 2013. Dünyada ve Türkiye'de arıcılık. Arıcılık Araştırma Dergisi, 10: 7 13.

Singh, J.M., 2002. On farm energy use pattern in different cropping systems in Haryana, India. MSc Thesis. International Institute of Management, University of Flensburg, Germany.

Topdemir, T., 2018. Determining energy and utilization efficiency of different tillage methods on cotton cultivation under Menemen plain conditions. MSc Thesis. Adnan Menderes University Graduate School of Natural and Applied Sciences, 111p, Aydın, Turkey. 